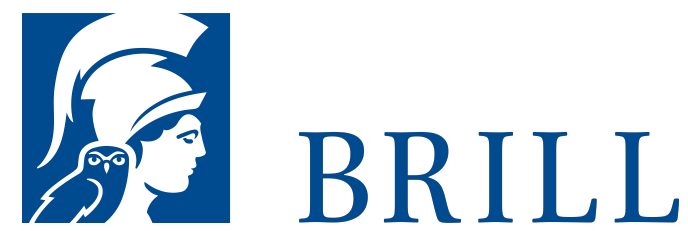

\title{
Kinderarbeit im Kaiserreich 1871-1914
}

\section{Author: Annika Boentert}

Obwohl die Kinderarbeit im 19. Jahrhundert nach wie vor zu den Standardthemen im Geschichtsunterricht gehört, ist ihre wissenschaftliche Aufarbeitung bisher überraschend lückenhaft geblieben. Im ihrem Mittelpunkt stand meist die Fabrikarbeit, während die zahlenmäßig sehr viel größeren Sektoren - die Hausindustrie, die Landwirtschaft und der Dienstleistungsbereich - nur am Rande erwähnt wurden. So blieben viele Fragen offen: Welche Arbeitszeiten z. B. hatte ein Hütejunge, was verdiente ein Kegelaufsetzer, gab es einen gesetzlichen Schutz für schulpflichtige Dienstmädchen? Wer setzte sich für die arbeitenden Kinder ein, warum und mit welchem Erfolg? Durch die Auswertung wenig bekannter Statistiken, die Schilderung typischer Einsatzbereiche (Zigarrenindustrie, Landwirtschaft u. a.) und einen internationalen Vergleich der Gesetzgebung leistet das Buch einen wichtigen Beitrag zur Korrektur dieser Schieflage. Die Berücksichtigung der unterschiedlichen Wirtschaftszweige führt zu einer Neubewertung der Einflussfaktoren, die den institutionellen Wandel der Kinderarbeit maßgeblich prägten: Die letzten Jahre des 19. Jahrhunderts rücken stärker ins Blickfeld, wichtiger als ökonomisch-technische Rationalisierungsbemühungen wird das Engagement politischer Persönlichkeiten und wichtiger Verbände. Eine neue, wegweisende Studie über die Kinderarbeit im deutschen Kaiserreich.

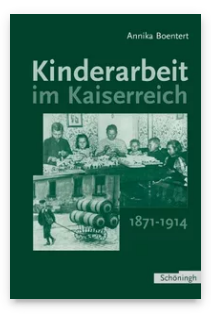

Pages: 476 Seiten, $19 \mathrm{~s} / \mathrm{w}$ Abb.

Language:

German

Subjects: Early

Modern History, History

Publisher: Brill |

Schöningh

E-Book (PDF)

Released online:

15 Jul 2019

ISBN: $978-3^{-}$

657-71357-8

List price

USD $\$ 84.00$

Paperback

Publication date:

24 Apr 2007

ISBN: 978-3-

506-71357-5

List price

USD $\$ 84.00$ 
For more information see brill.com

Order information: Order online at brill.com +44330 333 0049 | customerservices@brill.com Submission information: brill.com/authors

Titles published by Brill | Fink, Brill | mentis or Brill | Schöningh: +49(o)715413279216| brill@brocom.de 